Original Research

\title{
Air Pollution Associated with Sumatran Forest Fires and Mortality on the Malay Peninsula
}

\author{
Yu Jie* \\ School of Public Health, Zunyi Medical University, Zunyi, Guizhou, 563000, P.R. of China
}

Received: 14 June 2016

Accepted: 12 August 2016

\begin{abstract}
Background: The main study objective was to determine the associations between mean daily concentrations of criteria air pollutants and the risks of respiratory and cardiovascular mortality at hospitals in Malaysia's Klang Valley.

Methods: The study period was 1-31 August 2005. Two areas in the valley, Port Klang and Kuala Lumpur, and two areas in northwestern Malaysia, Penang and Langkawi, were selected. The study sample was all respiratory (ICD-10 J00-J99) and cardiovascular (ICD10 I10-I99) disease cases who were discharged as deceased from (for mortality data), the study hospitals during the study period. Air quality data on respirable particulate, nitrogen dioxide, sulphur dioxide, carbon monoxide, and ozone were obtained from continuous air quality monitoring stations located nearest to the hospitals in these four areas. Data on maximum temperature and rainfall were obtained from the four closest meteorological stations. Spearman correlation was then used to model the relationships between daily variations in the five air pollutants with variations in in-patient mortality statistics.

Results: Of the five criteria air pollutants, $\mathrm{PM}_{10}$ was the pollutant that exceeded the 24-hour average Malaysian Ambient Air Quality Guidelines (MAAQG) for $\mathrm{PM}_{10}$ of $150 \mu \mathrm{g} / \mathrm{m}^{3}$ 6-12 August in both Klang and Kuala Lumpur, and on 13 August in Penang and Langkawi. In Kuala Lumpur, the 24-hour mean temperature $(\mathrm{r}=0.586, \mathrm{p}<0.005)$ was directly correlated with $\mathrm{PM}_{10}$ concentration.

Conclusions: The variability of respiratory and cardiovascular case mortality in the four areas was not attributed to the change in the concentration of $\mathrm{PM}_{10}$ in ambient air over time. This outcome may be due to several factors such as the limitation in the area of influence of the 2005 haze episode in Malaysia, relatively lower concentrations of $\mathrm{PM}_{10}$ in ambient air, etc.
\end{abstract}

Keywords: air pollutants, $\mathrm{PM}_{10}$, respiratory diseases, cardiovascular diseases, Malaysia

\section{Introduction}

The 2005 Malaysian haze was a week-long choking smog-like haze over Malaysia that almost brought the

*e-mail: Xujie360@hotmail.com central part of peninsular Malaysia to a standstill and prompted crisis talks with Indonesia [1]. Lingering smoke from forest fires on the Indonesian island of Sumatra were identified as the primary cause. Farmers regularly burn scrub and forest to clear land during the dry season for agricultural purposes, but this was the worst haze that to hit Malaysia since the 1977 haze, when the daily average 
concentration of total suspended particles was about $297 \mu \mathrm{g} / \mathrm{m}^{3}$ of air in Kuala Lumpur [2].

On 11 August 2005 a state of emergency was announced for the world's $12^{\text {th }}$ largest port, Port Klang, and the district of Kuala Selangor after air pollution there reached dangerous levels. The state of emergency in the two affected areas meant the closing of schools, government offices, and the port.

Health authorities said asthma attacks had soared and tourists were hiding in their hotels or seeking refuge in air-conditioned shopping malls. Schools and one of Malaysia's key ports, Northport, were suspended. Shipping in the Malacca Straits was also affected by the haze. According to Malaysian Health Minister Chua Soi Lek, some government hospitals and clinics saw a $150 \%$ increase in respiratory complaints [3]. A high air pollutant index (API) reading was announced for the first time by the Malaysian government since 1997. (Malaysia's API closely follows the U.S. Environmental Pollution Agency's pollutant standard index; an API reading of 101200 is considered to be unhealthy, and an API of 301-500 is hazardous; Table 1). The following are API readings released by the Malaysian government during the onset of haze on 10 August 2005: Port Klang 424, Kuala Selangor 418, Shah Alam 349, Putrajaya 337, Petaling Jaya 304, Kuala Lumpur (KL) 276, and Malacca 107.

Although previous studies have determined the relationship between biomass haze and mortality regarding the 1997 Southeast Asian haze episode [4, 5], the 2005 haze episode was the worst to hit Malaysia since, and there was still a lack of information about the effects of haze pollution on human health. To our knowledge, this is the first study to investigate the relationship between biomass haze and mortality associated with the August 2005 Southeast Asian haze episode. The objective of this study is to determine the associations between mean daily concentrations of criteria air pollutants and the risks of respiratory and cardiovascular mortality in the Klang Valley. From this study, we can determine whether the government had enhanced haze pollution management and people had raised self-protection consciousness since the 1997 haze crisis, together with the haze health effect on residents.

As Malaysia becomes more developed, the cost of medical care (especially in-patient hospital care) escalates tremendously. This imposes a significant burden on the country's economy. Even though deteriorating air quality may not have a direct causal relationship with respiratory and cardiovascular diseases, it may exacerbate these diseases that lead to hospital admissions [6-11]. Deteriorating air quality may also cause premature mortality $[12,13]$. It would be interesting to know whether there exists a correlation between daily concentrations of criteria air pollutants and the risks of respiratory and cardiovascular mortality at hospitals in Malaysia's Klang Valley.

\section{Materials and Methods}

\section{Study Design}

A population-based, cross-sectional epidemiological survey of respiratory and cardiovascular diseases was conducted in Zunyi. The study was conducted 1-31 August 2005.

\section{Study Location}

The areas affected by the smoke haze from the Indonesian forest fires in August 2005 include the Klang Valley (Port Klang and Kuala Lumpur areas) and the Penang and Langkawi areas in northern Malaysia, which were affected more lightly [2]. At 2,832 $\mathrm{km}^{2}$, the Klang Valley is situated within the drainage basins of the Klang and Gombak rivers. The population in this area was more than 4.0 million in 2005. Penang is Malaysia's second smallest state with a total population of around

Table 1. Air pollutant index in Malaysia.

\begin{tabular}{|c|c|c|c|}
\hline API & Status & Level of pollution & Health measure \\
\hline $0-50$ & Good & Low, no ill effects on health & No restriction of activities for all groups \\
\hline $51-100$ & Moderate & $\begin{array}{l}\text { Moderate pollution no ill effects } \\
\text { on health }\end{array}$ & No restriction of activities for all groups \\
\hline $101-200$ & Unhealthy & $\begin{array}{l}\text { Mild aggravation of symptoms } \\
\text { among high risk groups, e.g., } \\
\text { those with heart or lung disease }\end{array}$ & $\begin{array}{l}\text { 1. Restriction of outdoor activities for high risk persons } \\
\text { 2. General population should reduce vigorous outdoor activity }\end{array}$ \\
\hline $201-300$ & $\begin{array}{c}\text { Very } \\
\text { unhealthy }\end{array}$ & $\begin{array}{l}\text { Significant aggravation of } \\
\text { symptoms and decreased } \\
\text { exercise tolerance in persons } \\
\text { with heart or lung disease }\end{array}$ & $\begin{array}{l}\text { 1. Elderly and persons with known heart or lung disease should stay } \\
\text { indoors and reduce physical activity } \\
\text { 2. General population should avoid vigorous outdoor activity } \\
\text { 3. Those with any health problems to consult doctor }\end{array}$ \\
\hline $301-500$ & Hazardous & $\begin{array}{l}\text { Severe aggravation of symptoms } \\
\text { and a danger to health }\end{array}$ & $\begin{array}{l}\text { 1. Elderly and persons with existing heart or lung disease should stay } \\
\text { indoors and reduce physical activity } \\
\text { 2. General population should avoid vigorous outdoor activity }\end{array}$ \\
\hline $501+$ & Emergency & $\begin{array}{l}\text { Severe aggravation of symptoms } \\
\text { and a danger to health }\end{array}$ & $\begin{array}{l}\text { 1. General population advised to follow the orders of the National security } \\
\text { council and always follow announcements through the mass media }\end{array}$ \\
\hline
\end{tabular}


Table 2. ASMA's continuous air quality monitoring (CAQM) stations in four study areas.

\begin{tabular}{|c|c|c|c|c|}
\hline Location ID & Name & Station Location & Longitude & Latitude \\
\hline CA001 & Sek. Men. Perempuan Raja Zarina & Klang & N03 00.620 & E101 24.484 \\
\hline CA0054 & Sek. Men. Keb. Sri Permaisuri & Kuala Lumpur Cheras & N03 06.376 & E101 43.072 \\
\hline CA0038 & Universiti Sains Malaysia & Penang & N05 21.528 & E100 17.864 \\
\hline CA0032 & Komplek Sukan Langkawi & Kedah & N06 19.903 & E099 51.517 \\
\hline
\end{tabular}

$1,578,000$ in 2005. Langkawi archipelago is a cluster of 99 islands with a much smaller island population of only 62,000 .

\section{Respiratory and Cardiovascular Mortality Data}

Our target population for the present study used all respiratory and cardiovascular disease patients admitted to hospitals in Penang and Langkawi. The data of respiratory and cardiovascular mortality were acquired from the three areas during the study period based on discharge data of patients discharged as deceased. The date of patient discharge was taken as the date of mortality. A total of 536 patients were surveyed. Of the 536, 282 and 254 had been admitted for cardiovascular and respiratory diseases, respectively. The cause of mortality was based on the patient's discharge diagnosis, which was classified according to the ICD 10 . The records contain a discharge diagnosis of the circulatory (codes 390-459) or respiratory (codes 460-519) systems.

\section{Air Quality Data}

Data on air quality in the valley plus Penang and Langkawi were obtained from the Alam Sekitar Malaysia Sdn. Bhd.'s (ASMA) continuous air quality monitoring (CAQM) stations located in these three areas, through assistance from the Department of the Environment

Table 3. Malaysian ambient air quality guidelines.

\begin{tabular}{|c|c|c|c|}
\hline \multirow{2}{*}{ Pollutant } & \multirow{2}{*}{$\begin{array}{c}\text { Averaging } \\
\text { time }\end{array}$} & \multicolumn{2}{|c|}{ Malaysian guideline } \\
\cline { 2 - 4 } & $\mathrm{ppm}$ & $\mu \mathrm{g} / \mathrm{m}^{3}$ \\
\hline $\begin{array}{c}\text { Particulate matter } \\
\left(\mathrm{PM}_{10}\right)\end{array}$ & 24 hour & & 150 \\
\cline { 2 - 4 } & 1 year & & 50 \\
\hline \multirow{2}{*}{ Nitrogen dioxide } & 1 hour & 0.17 & 320 \\
\cline { 2 - 4 } & 24 hour & 0.06 & 113 \\
\hline \multirow{3}{*}{ Sulphur dioxide } & 10 minutes & 0.19 & 500 \\
\cline { 2 - 4 } & 1 hour & 0.13 & 350 \\
\cline { 2 - 4 } & 24 hour & 0.04 & 105 \\
\hline \multirow{2}{*}{ Carbon monoxide } & 1 hour & 30 & 35 \\
\cline { 2 - 4 } & 8 hour & 9 & 10 \\
\hline \multirow{2}{*}{ Ozone } & 1 hour & 0.10 & 200 \\
\cline { 2 - 4 } & 8 hour & 0.06 & 120 \\
\hline
\end{tabular}

(Table 2). We obtained mean daily ambient concentrations of particulate matter less than 10 microns $\left(\mathrm{PM}_{10}\right)$ in $\mu \mathrm{g} / \mathrm{m}^{3}$, sulphur dioxide $\left(\mathrm{SO}_{2}\right)$ in $\mathrm{ppm}$, nitrogen dioxide $\left(\mathrm{NO}_{2}\right)$ in ppm, ozone $\left(\mathrm{O}_{3}\right)$ in ppm, and carbon monoxide (CO) in ppm. Each CAQM station is an integrated ambient air quality monitoring system designed to monitor ambient air for specific pollutants. These five criteria pollutant concentrations were recorded per hour in the monitoring system. Mean daily ambient concentration was calculated according to the monitored 24-hour concentrations.

The Malaysian Ambient Air Quality Guidelines (MAAQG) prescribes ambient guidelines for five criteria air pollutants as shown by Table 3 . In this study, five criteria pollutants were selected to assess their associations with patient mortality. These five pollutants were selected because they tend to have the greatest impacts on human health, especially on respiratory and cardiovascular mortality [14]. These five pollutants are also used in the API computation.

\section{Meteorological Data}

The Malaysian Meteorological Services provided data on daily maximum and minimum temperature, relative humidity, and rainfall. The data were obtained from three meteorological stations located respectively in the Klang Valley, Penang, and Langkawi. The distribution of meteorological monitoring stations in four study areas is shown in Table 4.

\section{Data Analysis}

The data were analyzed using SPSS-16.0 (SPSS Inc, Chicago, Illinois). The statistical significance of correlations between air pollutants and mortality, and air pollutants and meteorological data were assessed by Spearman correlation because these data were not normally distributed except for temperature and humidity

Table 4. Meteorological monitoring stations in four study areas.

\begin{tabular}{|c|c|c|}
\hline Station Location & Longitude & Latitude \\
\hline $\begin{array}{c}\text { Petaling Jaya } \\
\text { (Kuala Lumpur) }\end{array}$ & $101^{\circ} 39^{\prime} \mathrm{E}$ & $03^{\circ} 06^{\prime} \mathrm{N}$ \\
\hline Port Klang & $101^{\circ} 23^{\prime} \mathrm{E}$ & $03^{\circ} 01^{\prime} \mathrm{N}$ \\
\hline Bayan Lepas (Penang ) & $100^{\circ} 16^{\prime} \mathrm{E}$ & $05^{\circ} 18^{\prime} \mathrm{N}$ \\
\hline Pulau Langkawi & $99^{\circ} 44^{\prime} \mathrm{E}$ & $06^{\circ} 20^{\prime} \mathrm{N}$ \\
\hline
\end{tabular}


data recorded at Petaling Jaya, Langkawi, and Penang stations, and mortality case data recorded in Klang and Penang. A $p$ value $<0.05$ was considered as the level of statistical significance. The deceased patients did not necessarily die because of air pollution in the day of death but rather because of pollution from the previous day, and hence the correlation between daily mortality and the previous day air pollution indexes was analyzed.

\section{Results}

\section{Air Quality Data}

24-hour average Malaysian Ambient Air Quality Guidelines (MAAQG) for $\mathrm{PM}_{10}$ of $150 \mu \mathrm{g} / \mathrm{m}^{3}$ was exceeded during 6-12 August for Klang and KL stations. However, for Penang and Langkawi stations, 24-hour average MAAQG for $\mathrm{PM}_{10}$ of $150 \mu \mathrm{g} / \mathrm{m}^{3}$ was only exceeded on 13 August. The highest concentration of PM10 $(590 \mu \mathrm{g} /$ $\mathrm{m}^{3}$ ) was recorded on 10 August at Klang station, which is 3.93 times higher than the MAAQG for 24-hour $\mathrm{PM}_{10}$, $465 \mu \mathrm{g} / \mathrm{m}^{3}$ on 11 August at KL station, $238 \mu \mathrm{g} / \mathrm{m}^{3}$ on 13 August at USM Penang station, and $183 \mu \mathrm{g} / \mathrm{m}^{3}$ on 13 August at Langkawi station. The MAAQG for 24-hour $\mathrm{NO}_{2}, 24$-hour $\mathrm{SO}_{2}, 8$-hour $\mathrm{CO}$, and 8-hour $\mathrm{O}_{3}$ of $0.06 \mathrm{ppm}, 0.04 \mathrm{ppm}, 9 \mathrm{ppm}$, and $0.06 \mathrm{ppm}$, respectively, were never exceeded at any of the four stations during August.

As shown by Figure 1, seven days of the daily mean concentration of $\mathrm{PM}_{10}$ exceeded the MAAQG out of 31 days for Klang and KL stations. Three days of the daily mean concentration of $\mathrm{PM}_{10}$ exceeded the MAAQG out of August for Penang and Langkawi stations.

\section{Meteorological Data}

Complete data for the three indicators are available for the Petaling Jaya (Kuala Lumpur), Langkawi and Bayan Lepas (Penang) stations; there is only data of rainfall available for Port Klang station. As shown by Table 5, the 24-hour mean temperature was recorded highest on 1 August $\left(30.3^{\circ} \mathrm{C}\right)$ and lowest on 18 August $\left(25.4^{\circ} \mathrm{C}\right)$ at Petaling Jaya. The highest 24-hour mean humidity (86.9\%) was recorded at Bayan Lepas and the lowest (61.0\%) at Petaling Jaya. The highest 24-hour rainfall $(94.6 \mathrm{~mm})$ was recorded at Langkawi, and the mean rainfall ranged from $3.5 \mathrm{~mm}$ recorded at Port Klang to $13.5 \mathrm{~mm}$ recorded at Langkawi.

\section{Mortality Data}

The numbers of mortality cases in Klang, Kuala Lumpur, Penang, and Langkawi are 106, 217, 209, and 4 , respectively. Table 6 shows that among the three age groups, total respiratory and cardiovascular mortality of 56 and above age group (72.6\%) was highest, compared to the $16-54$ age group (24\%) and $<15$ age group $(3.4 \%)$.

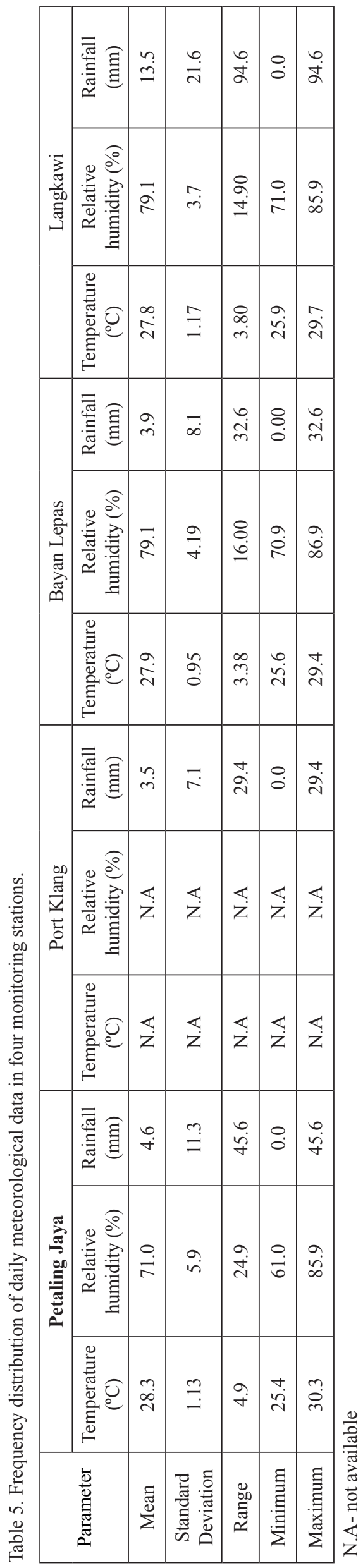


Table 6. Distribution of mortality data in four areas under study.

\begin{tabular}{|c|c|c|c|}
\hline $\begin{array}{c}\text { Age } \\
\text { group }\end{array}$ & $\begin{array}{c}\text { Respiratory } \\
\text { disease } \\
\text { (Number/ } \\
\text { percentage) }\end{array}$ & $\begin{array}{c}\text { Cardiovascular } \\
\text { disease } \\
\text { (Number/ } \\
\text { percentage) }\end{array}$ & $\begin{array}{c}\text { Total } \\
\text { (Number/ } \\
\text { percentage) }\end{array}$ \\
\hline$>15$ & $10(4 \%)$ & $8(3 \%)$ & $183(4 \%)$ \\
\hline $15-55$ & $61(24 \%)$ & $68(24 \%)$ & $129(24 \%)$ \\
\hline $\begin{array}{c}56 \text { and } \\
\text { above }\end{array}$ & $183(72 \%)$ & $206(73 \%)$ & $389(72.6 \%)$ \\
\hline Total & $254(100 \%)$ & $282(100 \%)$ & $536(100 \%)$ \\
\hline
\end{tabular}

The statistical analyses of the hospital mortality data on combined deaths for respiratory and cardiovascular diseases were done for four areas and for all local residents by air pollutants. The reason for combining respiratory and cardiovascular mortality was because the mortality counts were too few in number.

Table 7 gives the correlation of mortality for respiratory and cardiovascular cases at all hospitals by increments of each of the five air pollutant ambient concentrations. Of the five air pollutants, none of them was found to be associated with a significant correlation coefficient for respiratory and cardiovascular mortality.

\section{Correlation Analysis}

\section{Correlation of Air Quality Indicators with Meteorological Factors in Four Areas Under Study}

Twenty-four-hour mean temperature $(\mathrm{r}=0.586$, $\mathrm{p}=0.001)$ was directly correlated with $\mathrm{PM}_{10}$ in Kuala Lumpur (Fig. 2), whereas, 24-hour mean humidity $(\mathrm{r}=-0.110, \mathrm{p}=0.557)$ and rainfall $(\mathrm{r}=-0.144$, $\mathrm{p}=0.440$ ) were not directly correlated with $\mathrm{PM}_{10}$ in Kuala Lumpur. Twenty-four-hour rainfall $(\mathrm{r}=-0.124$, $\mathrm{p}=0.506)$ was not directly correlated with $\mathrm{PM}_{10}$ in Port Klang (Fig. 3). Twenty-four-hour mean temperature $(\mathrm{r}=0.563, \mathrm{p}=0.001)$ was directly correlated with $\mathrm{PM}_{10}$ in Port Klang, while 24-hour mean humidity $(r=-0.469$, $\mathrm{p}=0.008)$ was inversely directly correlated with $\mathrm{PM}_{10}$

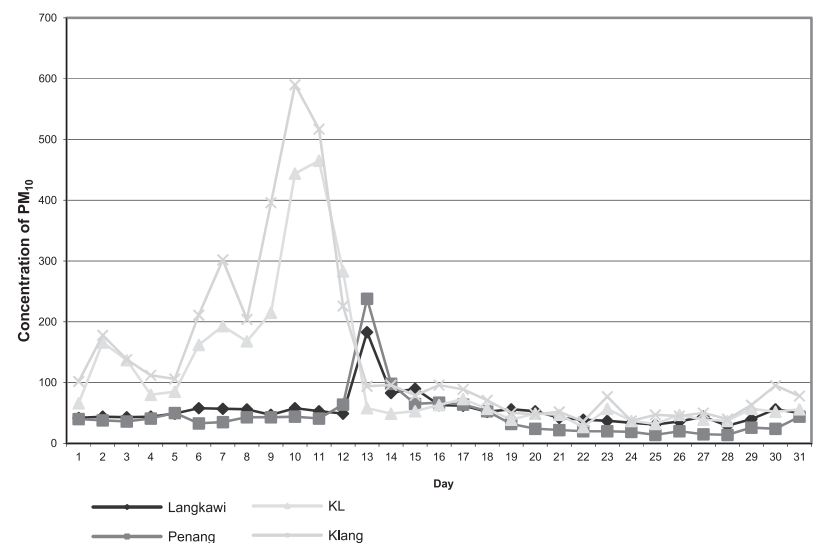

Fig. 1. Distribution of $\mathrm{PM}_{10}$ in four areas under study.

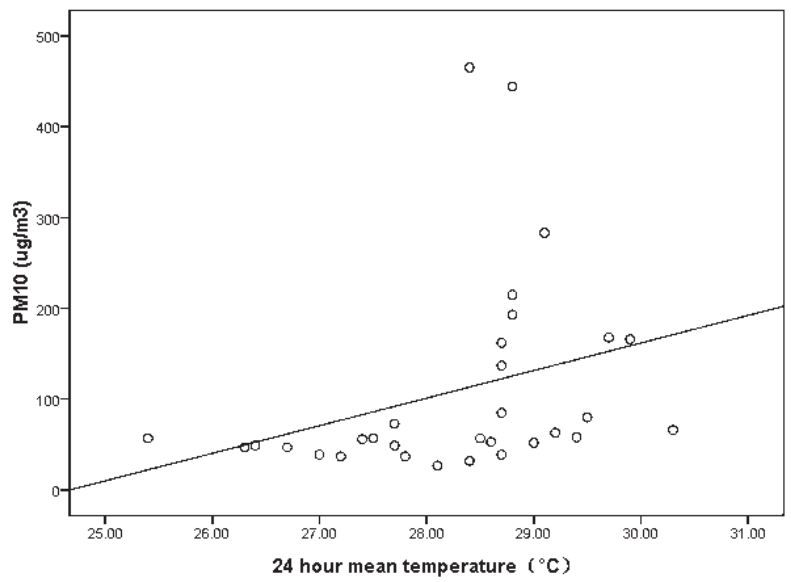

Fig. 2. Correlation scatter diagrams of air quality and meteorological parameters in Kuala Lumpur.

in Penang. Rainfall $(r=-0.422, p=0.018)$ was inversely directly correlated with $\mathrm{PM}_{10}$ in Penang.

Twenty-four-hour mean temperature $(r=0.632$, $\mathrm{p}=0.0001)$ was directly correlated with $\mathrm{PM}_{10}$ in Langkawi. Similarly, 24-hour mean humidity $(\mathrm{r}=-0.564, \mathrm{p}=0.001)$ and rainfall $(\mathrm{r}=-0.632, \mathrm{p}=0.0001)$ were inversely directly correlated with $\mathrm{PM}_{10}$ in Langkawi.

Table 7. Correlation and correlation coefficients between $\mathrm{PM}_{10}$ and meteorological factors and mortality in four areas.

\begin{tabular}{|c|c|c|c|c|c|c|c|c|}
\hline \multirow{3}{*}{ Variable } & \multicolumn{2}{|c|}{ Klang } & \multicolumn{2}{|c|}{ Kuala Lumpur } & \multicolumn{2}{|c|}{ Penang } & \multicolumn{2}{|c|}{ Langkawi } \\
\hline & \multicolumn{2}{|c|}{ PM10 (ug/m³) } & \multicolumn{2}{|c|}{ PM10 (ug/m³) } & \multicolumn{2}{|c|}{ PM10 (ug/m³) } & \multicolumn{2}{|c|}{ PM10 (ug/m³) } \\
\hline & $\mathrm{r}$ & $P$ value & $\mathrm{r}$ & $P$ value & $\mathrm{r}$ & $\mathrm{P}$ value & $\mathrm{r}$ & $P$ value \\
\hline Temperature & N.A & N.A & $0.586^{*}$ & 0.001 & $0.563^{*}$ & 0.001 & $0.632 *$ & 0.0001 \\
\hline Relative humidity & N.A & N.A & -0.110 & 0.557 & $-0.469 *$ & 0.008 & $-0.564 *$ & 0.001 \\
\hline Rainfall & -0.287 & 0.117 & -0.144 & 0.440 & $-0.422 *$ & 0.018 & $-0.632 *$ & 0.0001 \\
\hline Total mortality & -0.036 & 0.848 & 0.112 & 0.549 & 0.056 & 0.763 & 0.103 & 0.582 \\
\hline
\end{tabular}

N.A- not available. *Correlation is significant at the 0.05 level (2-tailed) 


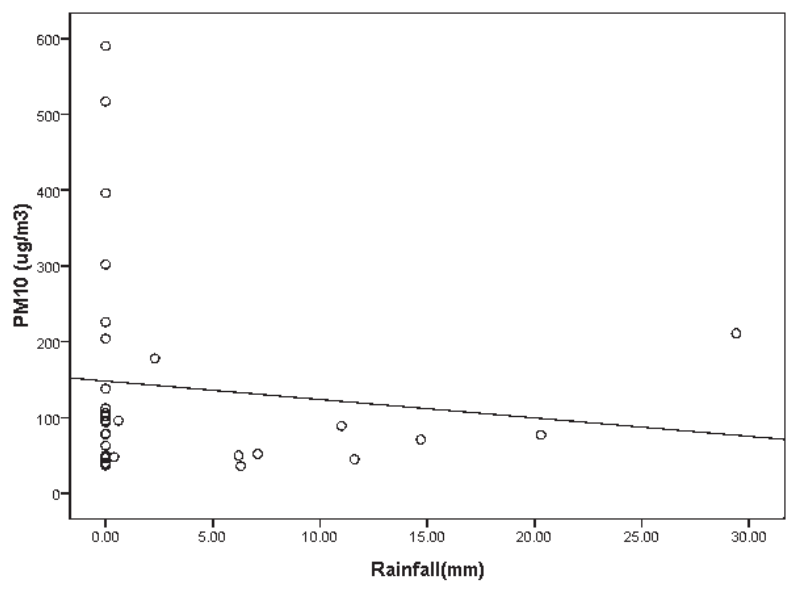

Fig. 3. Correlation scatter diagram of air quality and meteorological parameters in Port Klang.

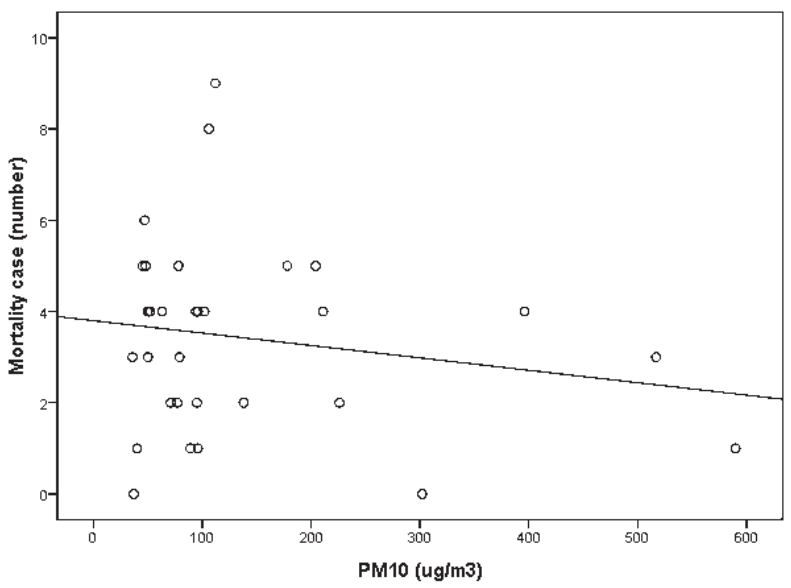

Fig. 4. Correlation scatter diagram of respiratory and cardiovascular mortality case and air quality parameters in Port Klang.

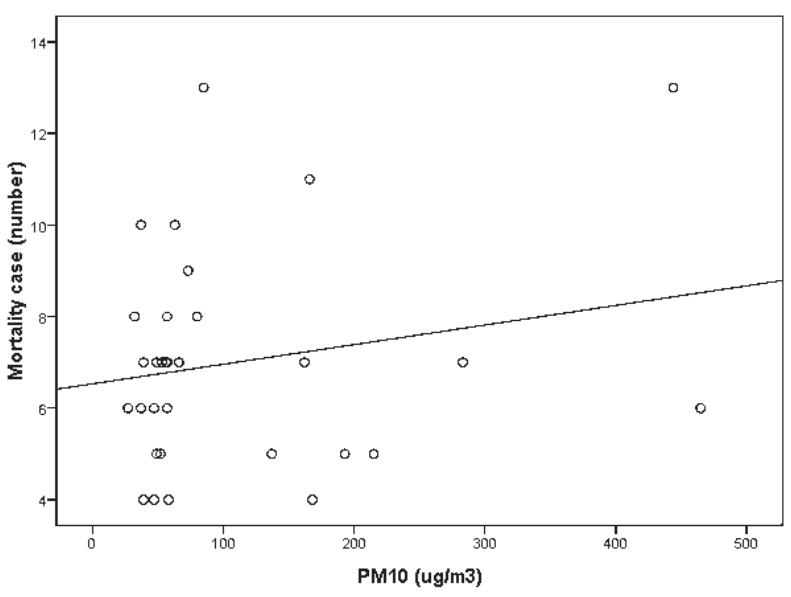

Fig. 5. Correlation scatter diagram of respiratory and cardiovascular mortality case and air quality parameters in Kuala Lumpur.
Correlation of Air Quality Indicators with Respiratory and Cardiovascular Mortality in Four Areas Under Study

In Port Klang, $\mathrm{PM}_{10}(\mathrm{r}=-0.179, \mathrm{p}=0.335)$ was not correlated with respiratory and cardiovascular mortality cases (Fig. 4).

$\mathrm{PM}_{10}(\mathrm{r}=0.198, \mathrm{P}=0.286)$ was not correlated with respiratory and cardiovascular mortality cases in Kuala Lumpur (Fig. 5), in Penang, PM10 ( $\mathrm{r}=0.056, \mathrm{P}=0.763$ ), or in Lankawi, $\mathrm{PM}_{10}(\mathrm{r}=0.103, \mathrm{P}=0.582)$.

\section{Correlation of Air Quality Indicators with Meteorological Factors in Three Areas Under Study}

The 24-hour mean temperatures were not directly correlated with $\mathrm{PM}_{10}$ in Kuala Lumpur, $(\mathrm{r}=0.247$, $\mathrm{P}=0.181)$ Penang $(\mathrm{r}=-0.190, \mathrm{P}=0.305)$, or Langkawi $(r=0.045, P=0.810)$ (Figs 6-8).

\section{Discussion}

The associations between air pollution and respiratory and cardiovascular morbidity and mortality have been well established by many researchers throughout the world ever since the fateful incident of the London Fog of December 1952, when the average concentration of particulate matter was $4.46 \mathrm{mg} / \mathrm{m}^{3}$ of air [15]. During the August 2005 haze episode, the main air pollutant in ambient air is $\mathrm{PM}_{10}$, and the 24-hour average MAAQG for $\mathrm{PM}_{10}$ of $150 \mu \mathrm{g} / \mathrm{m}^{3}$ was exceeded between 6-12 August in Klang and KL, and on 13 August in Penang and Langkawi. Maximum daily $\mathrm{PM}_{10}$ concentrations were $590 \mathrm{ug} / \mathrm{m}^{3}$ in Klang, $465 \mathrm{ug} / \mathrm{m}^{3}$ in KL, $183 \mathrm{ug} / \mathrm{m}^{3}$ in Penang, and $238 \mathrm{ug} / \mathrm{m}^{3}$ in Langkawi, respectively. Although the level of $\mathrm{PM}_{10}$ exceeded MAAQG in these four areas, the variation of respiratory and cardiovascular mortality of people in the four four areas was not attributed to the change of concentration of $\mathrm{PM}_{10}$ in ambient air, and the correlation coefficient of case admissions for $\mathrm{PM}_{10}$ increment were not significant in the four areas. This outcome may be due to several factors such as the limitation in the area of influence of 2005 haze episode in Malaysia, relatively lower concentrations of $\mathrm{PM}_{10}$ in ambient air, a shorter period (one month) of haze during which people were exposed, and the fact that the resulting air pollutants did not trigger respiratory and cardiovascular disease death due to good emergency medical services. This is the first study in Malaysia during August 2005 reporting the effects of haze pollution on daily mortality, and our results might contribute to an understanding of pollution levels during the Malaysian haze episode.

Our research result seem not to agree with the observations made by Narayan Sastry, who found that the smoke haze significantly increased the mortality burden for the population in Malaysia in the 1997 haze episode. The authors used Poisson regression to model the daily 


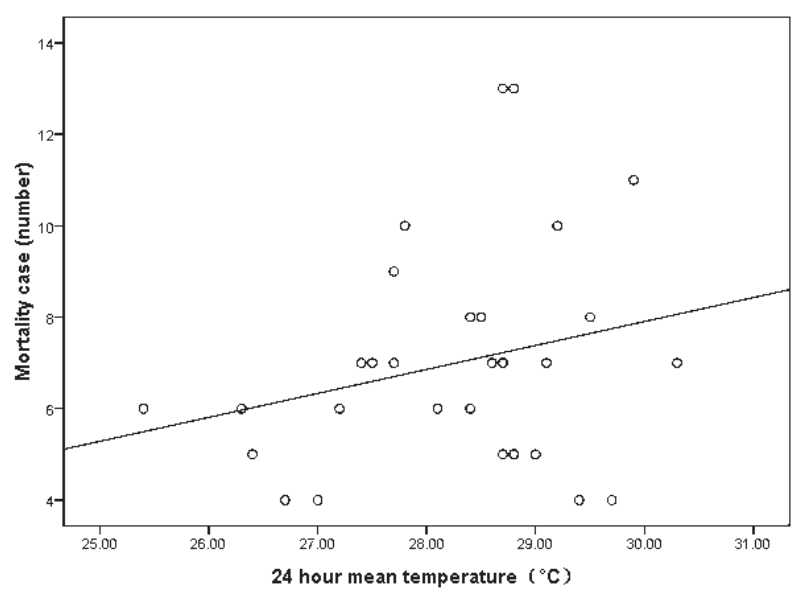

Fig. 6. Correlation scatter diagrams of 24 hour mean temperature and respiratory and cardiovascular mortality case in Kuala Lumpur.

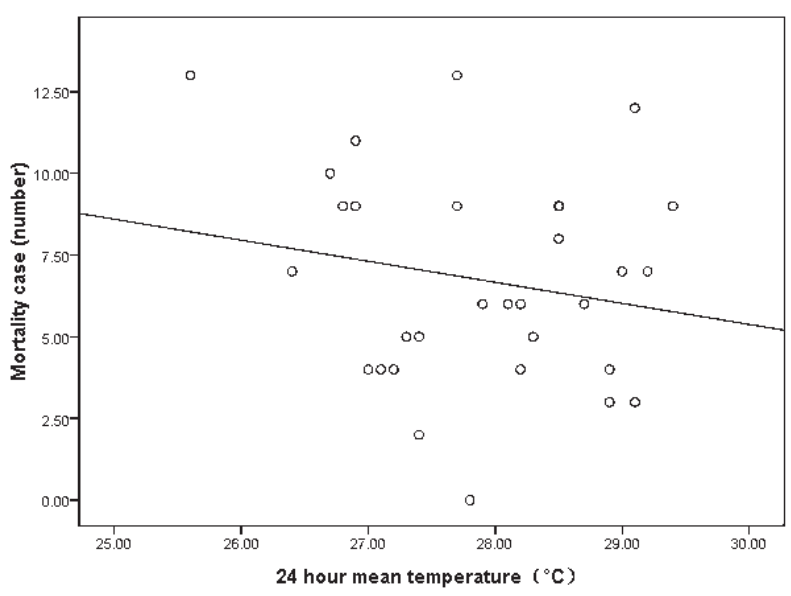

Fig. 7. Correlation scatter diagrams of 24 hour mean temperature and respiratory and cardiovascular mortality case in Penang.

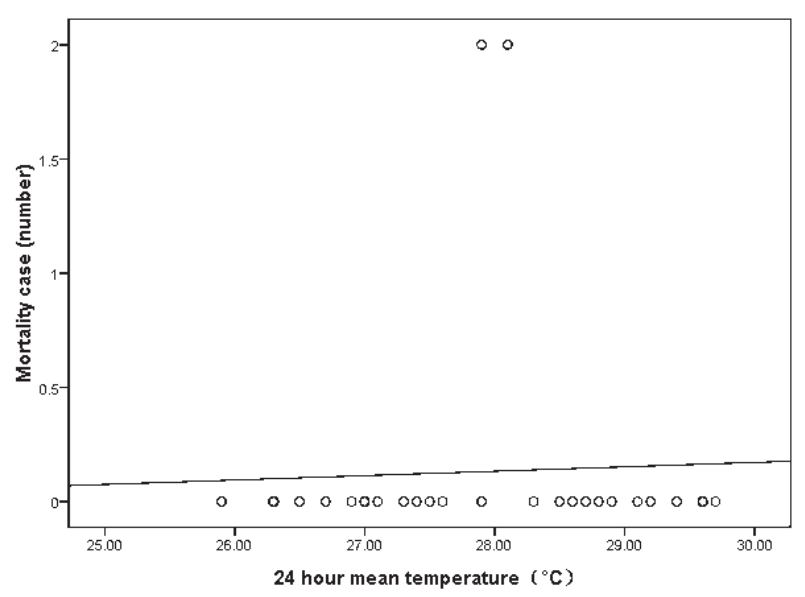

Fig. 8. Correlation scatter diagrams of 24 hour mean temperature and respiratory and cardiovascular mortality case in Langkawi. counts of mortality as the dependent variables, while time, temperature, rainfall, and air pollutant concentrations act as the independent variables [16]. Compared with the prior results, our estimates were lower. This fact may reflect differences in the statistical techniques we used as well as local PM levels. Population sensitivity to PM, age distribution, and especially different particle components may strongly affect the exposure-response relationships. In addition, inconsistent with several time series studies [17-19], we used the non-parameter Spearman correlation analysis (in SPSS software) for our data analysis. Most prior air pollution time-series studies have been based on the GAM model in S-PLUS. Earlier simulation studies have shown that various regression models and parameter setting in the models (e.g., df selection, convergence criteria) would affect the regression coefficients [20].

The characteristics of the study site and statistical approach in our study were different compared with previous studies, we only investigated the overall acute effects on human health on posterior days with spearman correlation statistical analysis. The findings in this study were consistent with the observations made by Analitis (2006), who found that an increase in $\mathrm{PM}_{10}$ by $10 \mu \mathrm{g} / \mathrm{m}^{3}$ (lag $0+1$ ) was associated with increases of $0.76 \%$ in cardiovascular deaths and $0.58 \%$ in respiratory deaths. Analitis et al. applied a two-stage hierarchical modeling approach assessing city-specific effects first and then overall effects using the one-day moving average of current and posterior day concentrations of particles $(\operatorname{lag}=01)[21]$.

Our findings show that 24-hour mean temperatures were not directly correlated with $\mathrm{PM}_{10}$ in Kuala Lumpur, Penang, and Langkawi, which is not in agreement with an investigation performed in 384 locations around the world [22]. Gasparrini reported that most of the temperature-related mortality burden was attributable to the contribution of cold. In this study, the 24-hour mean temperature was recorded highest on 1 August $\left(30.3^{\circ} \mathrm{C}\right)$ and lowest on 18 August $\left(25.4^{\circ} \mathrm{C}\right)$ at Petaling Jaya. As expected for a tropical country like Malaysia, the variation in temperature over the study period was very small. The temperature in Malaysia remains at a fairly constant 28$32^{\circ} \mathrm{C}$ year round. The tropical climate factors may explain the difference in the two study results.

The limitations of our study should be noted. As in other time-series studies, we used available outdoor monitoring data to represent the population exposure to ambient particles. The resulting measurement error may have implications for interpreting the effect of particles, although a study suggested that this measurement error would generally tend to bias estimates downward [23]. However, we lack information on personal exposure to particles to quantify this bias. Another limitation is that our assessment of ambient particles was derived entirely from one monitoring station in each of three areas. Compared with studies in Europe and North America, the data we collected were also limited by virtue of the single city and limited time period. This may have limited our power to find significant association with air pollutants. 
As in other time-series studies, we did not consider the particles from indoor sources. In Kuala Lumpur, little or no indoor air monitoring data are available. However, some studies suggested that the daily population average concentrations of particles derived from indoor sources are approximately independent of ambient levels [24]. When this is true, failure to measure indoor sources will not introduce further bias in the estimated effects of ambient particles [25].

\section{Conclusion}

In this study, 24-hour average MAAQG for $\mathrm{PM}_{10}$ of $150 \mu \mathrm{g} / \mathrm{m}^{3}$ was exceeded on 6-12 August for Klang Valley station, where the highest concentration of $\mathrm{PM}_{10}$ $\left(590 \mu \mathrm{g} / \mathrm{m}^{3}\right)$ was recorded on 10 August. In Kuala Lumpur, the 24-hour mean temperature was directly correlated with $\mathrm{PM}_{10}$ concentration. Our analyses provide the first study during the August 2005 haze episode in Malaysia to associate mortality with ambient pollutants. The coordinated flow of information to the public and practical advice on mitigation measures such as the use of air cleaners and masks is crucial in the management of a smoke haze emergency. In Malaysia, the main emphasis in the 2005 smoke haze episode has been on strengthening and fine-tuning the provision of timely information on the severity of air pollution and appropriate health advisories for members of the public.

\section{Acknowledgements}

This work was supported by the 2015 Fund for key discipline construction in Zunyi Medical University (No.0996034).

\section{References}

1. SANSUDDIN N., RAMLI N.A., YAHAYA A.S., YUSOF N.F., GHAZALI N.A., MADHOUN W.A. Statistical analysis of $\mathrm{PM}_{10}$ concentrations at different locations in Malaysia. Environ Monit Assess. 180 (1-4), 573, 2011.

2. RADZI BIN ABAS M., OROS D.R., SIMONEIT B.R. Biomass burning as the main source of organic aerosol particulate matter in Malaysia during haze episodes. Chemosphere. 55 (8), 1089, 2004.

3. KWEH R.H.C., LEE J.H., LIU W.H., SAMUEL S.J.Q., SHARON X. Raffles Institution - Report on Singapore Raffles Institution Working Group. 2007. A Hazy Situation. (online) Available at: http://library.thinkquest. org/06aug/02304/final/lowbandwidthver/printable.pdf Accessed on 6 January 2015.

4. KUNII O., KANAGAWA S., YAJIMA I., HISAMATSU Y., YAMAMURA S., AMAGAI T., ISMAIL I.T The 1997 haze disaster in Indonesia: its air quality and health effects. Arch Environ Health; 57 (1), 16, 2002.

5. AFROZ R., HASSAN M.N., IBRAHIM N.A Review of air pollution and health impacts in Malaysia. Environ Res. 92 (2), 71, 2003.
6. JIE Y., HOUJIN H., XUN M., KEBIN L., XUESONG Y., JIE X. Relationship between pulmonary function and indoor air pollution from coal combustion among adult residents in an inner-city area of southwest China. Braz J Med Biol Res. 47 (11), 982, 2014.

7. YU JIE, NOOR HASSIM ISMAIL, XU JIE, ZALEHA MD ISA Do indoor environments influence on asthma and asthma-related symptoms among adults in homes? A review of the literature $[\mathrm{J}]$. Journal of the Formosan Medical Association. 110 (9), 555, 2011.

8. YU JIE, ZALEHA MD ISA, XU JIE, et al. Noor Hassim Ismail. Urban vs. Rural Factors that Affect Adult Asthma. Reviews of Environmental Contamination and Toxicology. 226, 33, 2013.

9. JIE Y., HOUJIN H., MENGXUE Y., WEI Q., JIE X A time series analysis of ambient temperature and hospital admissions for cardiovascular disease in northern district of Guizhou Province, China. Braz J Med Biol Res. 47 (8), 689, 2014.

10. JIE Y., ISA Z.M., JIE X., ISMAIL N.H. Asthma and asthmarelated symptoms among adults of an acid rain-plagued city in Southwest China: Prevalence and risk factors [J]. Polish Journal of Environmental Studies. 22 (3), 717, 2013.

11. JIE Y., JU Z.L., LI L.X., HAI J., JIE X. The impact of ambient temperature on pulmonary morbidity among the urban population in Zunyi, China [J]. Polish Journal of Environmental Studies. 22 (3), 707, 2013.

12. KOWALSKI M., KOWALSKA K., KOWALSKA M. Health benefits related to the reduction of PM concentration in ambient air, Silesian Voivodeship, Poland. Int J Occup Med Environ Health. 29 (2), 209, 2016.

13. OSTRO B., TOBIAS A., QUEROL X., ALASTUEY A., AMATO F., PEY J., PÉREZ N., SUNYER J. The effects of particulate matter sources on daily mortality: a casecrossover study of Barcelona, Spain. Environ Health Perspect. 119 (12), 1781, 2011.

14. WENG C.H., HU C.C., YEN T.H., HUANG W.H. Association between environmental particulate matter and arterial stiffness in patients undergoing hemodialysis. BMC Cardiovasc Disord. 15, 115, 2015.

15. SCOTT J.A. Fog and deaths in London, December 1952. Public Health Rep. 68 (5), 474, 1953.

16. NARAYAN SASTRY. FOREST FIRES Air Pollution, and Mortality in Southeast Asia. Demography 39, 1, 2002.

17. OSTRO B., BROADWIN R., GREEN S., FENG W.Y., LIPSETT M. Fine particulate air pollution and mortality in nine California counties: results from CALFINE. Environ Health Perspect 114 (1), 29, 2006.

18. PENG R.D., DOMINICI F., LOUIS T.A. Model choice in time series studies of air pollution and mortality. Journal of the Royal Statistical Society, Series A 169 (2), 179, 2006.

19. SAMOLI E., AGA E., TOULOUMI G., NISIOTIS K., FORSBERG B., LEFRANC A., PEKKANEN J., WOJTYNIAK B., SCHINDLER C., NICIU E., BRUNSTEIN R., DODIC FIKFAK M., SCHWARTZ J., KATSOUYANNI K. Short-term effects of nitrogen dioxide on mortality: an analysis within the APHEA project. Eur Respir J 27 (6), 1129, 2006.

20. DOMINICI F., PENG R.D., BELL M.L., PHAM L., MCDERMOTT A., ZEGER S.L., SAMET J.M. Fine particulate air pollution and hospital admission for cardiovascular and respiratory diseases. Jama; 295 (10), 1127, 2006.

21. ANALITIS A., KATSOUYANNI K., DIMAKOPOULOU K., SAMOLIE., NIKOLOULOPOULOSA.K.,PETASAKIS Y., TOULOUMI G., SCHWARTZ J., ANDERSON H.R., 
CAMBRA K., FORASTIERE F., ZMIROU D., VONK J.M., CLANCY L., KRIZ B., BOBVOS J., PEKKANEN J. Short-term effects of ambient particles on cardiovascular and respiratory mortality. Epidemiology 17, 230, 2006.

22. ANTONIO G., YU M.G., MASAHIRO H., ERIC L., ANTONELLA Z., JOEL S., AURELIO T., SHILU T., JOACIM R., BERTIL F., MICHELA L., MANUELA D.S., MICHELLE L.B., YUE L.L.G, CHANG F.W., KAN H.D., YI S.M., MICHELINE S.Z.S.C., PAULO H.N.S., YASUSHI H.,HO K., BEN A. Mortality risk attributable to high and low ambient temperature: a multicountry observational study. Lancet. 386 (9991), 369, 2015.

23. SAMET J.M., DOMINICI F., ZEGER S.L., SCHWARTZ J., DOCKERY D.W. The National Morbidity, Mortality, and Air Pollution Study. Part I: Methods and methodologic issues. Res Rep Health Eff Inst 94 (Pt 1), 5, 75, 2000.

24. WILSON W.E., SUH H.H. Fine particles and coarse particles: concentration relationships relevant to epidemiologic studies. J Air Waste Manag Assoc 47 (12), 1238, 1997.

25. ZEGER S.L., THOMAS D., DOMINICI F., SAMET J.M., SCHWARTZ J., DOCKERY D., COHEN A. Exposure measurement error in time-series studies of air pollution: concepts and consequences. Environ Health Perspect 108 (5), 419, 2000. 
